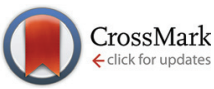

Cite this: Org. Biomol. Chem., 2016, 14, 5574

Received 4th February 2016, Accepted 7th March 2016

DOI: $10.1039 / \mathrm{c} 6$ ob00292g

www.rsc.org/obc

\section{Probing the self-assembly and stability of oligohistidine based rod-like micelles by aggregation induced luminescence $\uparrow$}

\author{
Hendrik Frisch, ${ }^{a}$ Daniel Spitzer, ${ }^{a}$ Mathias Haase, ${ }^{b}$ Thomas Basché, ${ }^{b}$ Jens Voskuhl*c \\ and Pol Besenius*a
}

\begin{abstract}
The synthesis and self-assembly of a new $C_{2}$-symmetric oligohistidine amphiphile equipped with an aggregation induced emission luminophore is reported. We observe the formation of highly stable and ordered rod-like micelles in phosphate buffered saline, with a critical aggregation concentration below $200 \mathrm{nM}$. Aggregation induced emission of the luminophore confirms the high stability of the anisotropic assemblies in serum.
\end{abstract}

Self-assembly of small molecules into macromolecular and polymeric architectures in water has been an increasingly popular synthetic strategy in organic materials chemistry since the pioneering work on supramolecular polymers 25 years ago. ${ }^{1,2}$ The use of directional non-covalent interactions in the molecular subunits can yield highly ordered one-dimensional supramolecular assemblies. ${ }^{3-9}$ These display dynamic behaviour and possess biological function that are not accessible through conventional covalent polymers. ${ }^{10}$ Particularly powerful design motifs to produce nanoscopic and ordered polymers in water are synthetic oligopeptides, using for example cyclic designs, ${ }^{11,12}$ aliphatic $^{13-15}$ or aromatic amphiphiles, ${ }^{16,17}$ and dendritic oligopeptides. ${ }^{18,19}$ Promising biological function ${ }^{20}$ arises through applications as drug delivery vehicles, ${ }^{21-28}$ vaccines, ${ }^{29-32}$ imaging agents $^{33,34}$ or supports for tissue engineering. ${ }^{15,35-38}$

To date, we have focused our attention on preparing dynamic supramolecular nanorods obtained via the selfassembly of $C_{3}$-symmetric amphiphilic peptides, ${ }^{19,39-42}$ and luminescent spherical micelles or 2D-sheets based on linear $\mathrm{Au}(\mathrm{I})$-metallopeptides. ${ }^{43}$ Here we report a new $C_{2}$-symmetric

\footnotetext{
${ }^{a}$ Institute of Organic Chemistry, Johannes Gutenberg-Universität Mainz, Duesbergweg 10-14, D-55128 Mainz, Germany.E-mail: besenius@uni-mainz.de;

Tel: +49-6131-39-22355

${ }^{b}$ Institute of Physical Chemistry, Johannes Gutenberg-Universität Mainz, Duesbergweg 10-14, D-55128 Mainz, Germany

${ }^{c}$ Institute of Organic Chemistry, University of Duisburg-Essen, Universitätsstrasse 7, D-45117 Essen, Germany. E-mail:jens.voskuhl@uni-due.de; Tel: +49-201-183-2404 $\dagger$ Electronic supplementary information (ESI) available: Additional Fig. S1-S6, detailed Experimental section: materials, synthesis, characterisation, analysis, methods and instrumentation. See DOI: 10.1039/c6ob00292g
}

oligohistidine amphiphile equipped with an aggregation induced emission luminophore. ${ }^{44-49}$ The development of intrinsically luminescent supramolecular assemblies is of high interest, since it avoids the need for additional labelling of monomers. In addition self-assembling luminophores that operate in luminescence "turn-on" mode further allow one to probe and track self-assembled states in more complex media, ${ }^{50,51}$ for example serum where highly abundant proteins make the use of electron microscopy and conventional luminescence "turn-off" probes very challenging.

The self-assembly unit is based on a $C_{2}$-symmetric 4,5 -bis(phenylthio)phthalonitrile (BPTP) as the central hydrophobic moiety extended with a $\beta$-sheet encoded alternating phenyl alanine-histidine peptide sequence (FHFHF) which bears a C-terminal hydrophilic polycationic dendron (Fig. 1A). The synthetic route is based on a convergent approach. ${ }^{52}$ We have incorporated hydrophobic $\mathrm{FH}$ alternating amino acid sequences in the side arm of the self-assembly unit, including an apolar hexyl-spacer separating the hydrophobic block from the water solubilising dendritic amine block (Fig. 1). The BPTP luminescent core was prepared by reacting 4,5-dichlorophthalonitrile first with 4-hydroxythiophenol, then with bromo-tertbutyl acetic acid in two high yielding steps. After deprotection of the C-terminal carboxylic acid, PyBOP mediated amidation of $\mathbf{4}$ with the protected dendronised peptide $\mathbf{8}$, and subsequent deprotection of the histidine as well as the primary amine functional groups yielded the target molecule 1. The detailed synthesis, purification and full characterisation of all intermediates can be found in the ESI. $\dagger$

In order to investigate the morphology of self-assembled $C_{2}$-symmetrical peptide amphiphile $\mathbf{1}$, we carried out negative stain transmission electron microscopy (TEM) experiments. ${ }^{40}$ Solutions of 1 at $100 \mu \mathrm{M}$ concentrations in Tris buffer $(10 \mathrm{mM})$ at $\mathrm{pH} 7.4$ showed one-dimensional semiflexible objects with a length that could not be resolved ( $>500 \mathrm{~nm})$ and an average thickness of $7.0 \pm 1.4 \mathrm{~nm}$ (Fig. 1B). The diameter of the rods is twice as large as expected compared to the approximated chain extended length of a single molecule of about $3.7 \mathrm{~nm}$. The semi-flexible rods are therefore best described as 
A)

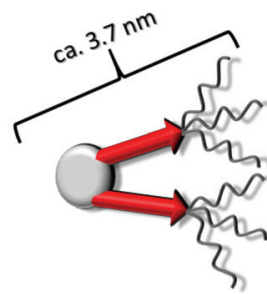<smiles>N#Cc1cc(OCC(=O)O)cc(-c2ccc(OCC(=O)O)cc2)c1</smiles>

$$
\mathrm{R}=
$$
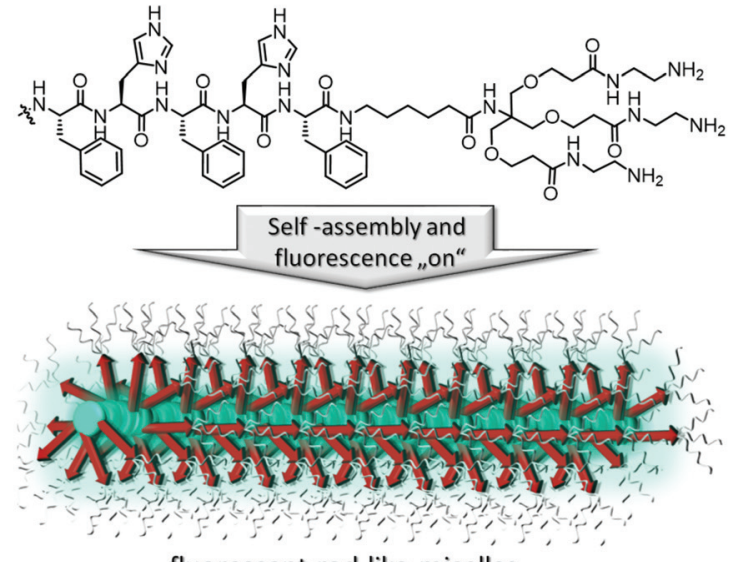

fluorescent rod-like micelles

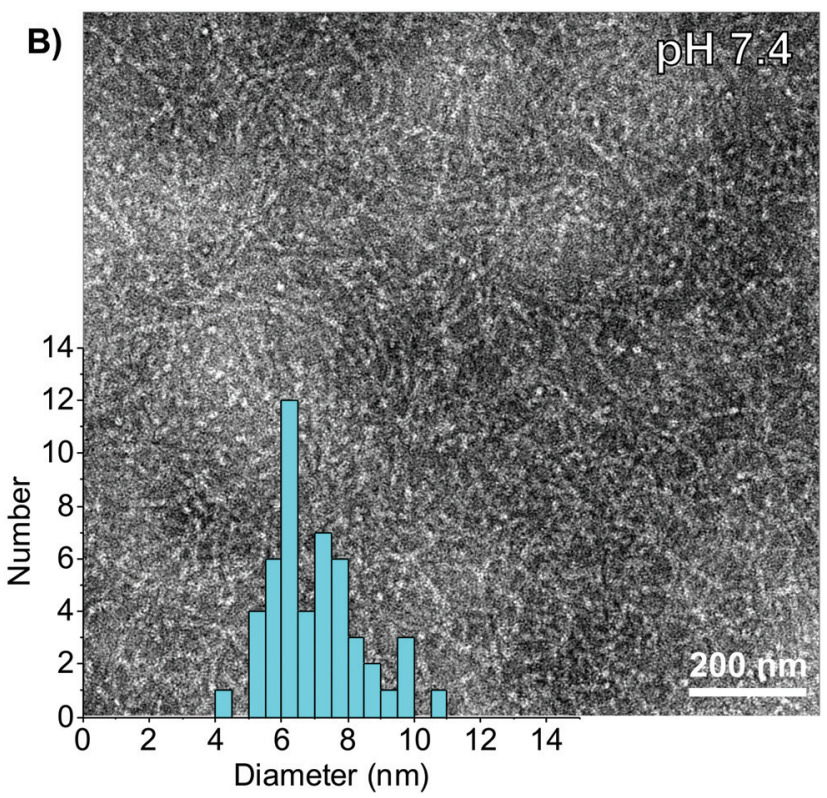

Fig. 1 (A) Schematic representation of the self-assembly of $C_{2}$-symmetric cationic peptide amphiphiles 1 into luminescent rod-like micelles; (B) negative stain TEM image of the rod-like micelles (deposited from a $100 \mu \mathrm{M}$ solution of 1 in Tris buffer $(10 \mathrm{mM}, \mathrm{pH}=7.4))$ and the distribution of the rod diameter.

micellar-like arrangement of amphiphiles with the hydrophobic block pointing into the core of one-dimensional assemblies, solvated via the cationic dendrons in the shell.

Circular dichroism (CD) spectroscopy experiments were carried out in order to gain insight into the molecular order of these nanostructures. The CD spectra of solutions of 1 analysed via TEM showed a minimum at around $216 \mathrm{~nm}$, which is characteristic of supramolecular assemblies with a high content of $\beta$-sheet secondary structure (Fig. 2) ${ }^{53}$ This indicates that the high level of molecular order leading to the formation of anisotropic nanostructures arises from the formation of hydrogen-bonded $\beta$-sheet domains along the fibre axis, which is well known for the self-assembly of peptide amphiphiles. ${ }^{13,54,55}$

In order to confirm that the self-assembly is driven by the hydrophobicity of the BPTP moiety and the peptide sequence, assisted by hydrogen bonding we performed disassembly experiments using a chemical denaturant. The addition of an UV-transparent organic solvent like methanol leads to the disruption of the hydrophobic shielding of the hydrogen bonding sequences and therefore disassembly of $1 .^{39,41,42} \mathrm{CD}$ spectra show the disappearance of the $\beta$-sheet characteristic negative $\mathrm{CD}$ band at $216 \mathrm{~nm}$ and a new positive $\mathrm{CD}$ band at $220 \mathrm{~nm}$ appears, which we have previously assigned to molecularly dissolved building blocks based on alternating hydrophobic and hydrophilic sequence pairs of phenyl alanine and glutamic acid (FEFEF) or phenyl alanine and lysine (FKFKF). ${ }^{40,52}$ It is interesting to point out that by lowering the $\mathrm{pH}$ value, we could not observe the same changes in the $\mathrm{CD}$ spectra compared to the spectra recorded in methanol. We initially expected the protonation of the histidine to increase the hydrophilicity of the peptide side arms and thereby induce disassembly, similar to our previous work on the $C_{3}$-symmetric FXFXF sequences. Note that a reduction in the $\beta$-sheet band at $216 \mathrm{~nm}$ by $31 \%$ is indicative of a decrease in the degree of order, but not full disassembly, likely due to protonation and swelling in the peptide core. These pH-titrations are indicative of highly stable assemblies. In summary, the TEM and CD experiments in buffered aqueous media demonstrate the self-assembly into ordered and stable rod-like micelles.

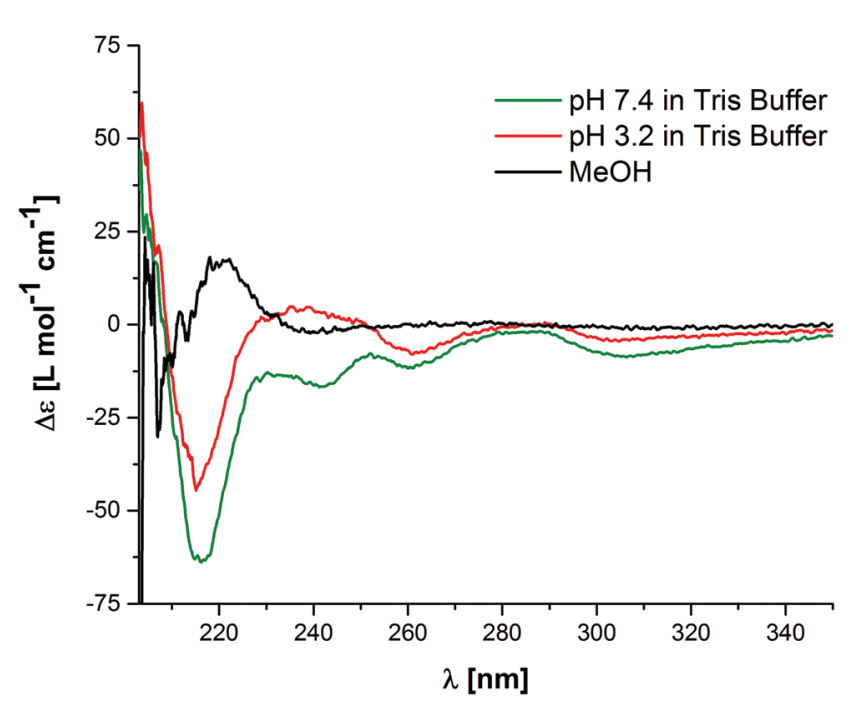

Fig. $2 \mathrm{CD}$ experiments of self-assembled 1 in buffered water (Tris buffer, $10 \mathrm{mM}$ ) at $\mathrm{pH}$ values of 7.4 (green curve, $100 \mu \mathrm{M}$ ) and 3.2 (red curve, $100 \mu \mathrm{M}$ ) and the disassembled state recorded in methanol (black curve, $25 \mu \mathrm{M}$ ). 
To investigate whether the luminescence properties of BPTP can be utilised to probe the self-assembly of $\mathbf{1}$ in various media, we first of all performed a series of photoluminescence spectroscopy measurements of $\mathbf{1}$ in $\mathrm{DMSO} / \mathrm{H}_{2} \mathrm{O}$ mixtures (Fig. 3A). Similarly to $\mathrm{MeOH},+\mathrm{DMSO}$ is an efficient denaturant since it is known to disrupt hydrogen bonded assemblies in water. ${ }^{56,57}$ Upon increasing the water content in DMSO from 0-40 vol\% we observe an increase in the emission band at $\lambda_{\text {em }}=460 \mathrm{~nm}$ (Fig. 3B). At $50 \mathrm{vol} \% \mathrm{H}_{2} \mathrm{O}$ the emission intensity reaches a plateau value, which is indicative of a fully aggregated state. The observed aggregation induced emission (AIE) of 1 most likely arises from a combination of the restriction of intramolecular motions (RIM) ${ }^{49}$ and twisted intramolecular charge transfer (TICT). ${ }^{58}$ In the aggregated state the intramolecular rotations and vibrations of $\mathbf{1}$ are restricted, blocking radiationless relaxation channels and promoting the radiative decay pathway. Furthermore, solvatochromic effects like TICT could influence the luminescence, since in DMSO the molecularly dissolved $\mathbf{1}$ is exposed to a highly polar environment, while upon aggregation in $\mathrm{H}_{2} \mathrm{O}$ the luminophore is embedded in the apolar inner core of the micelles.
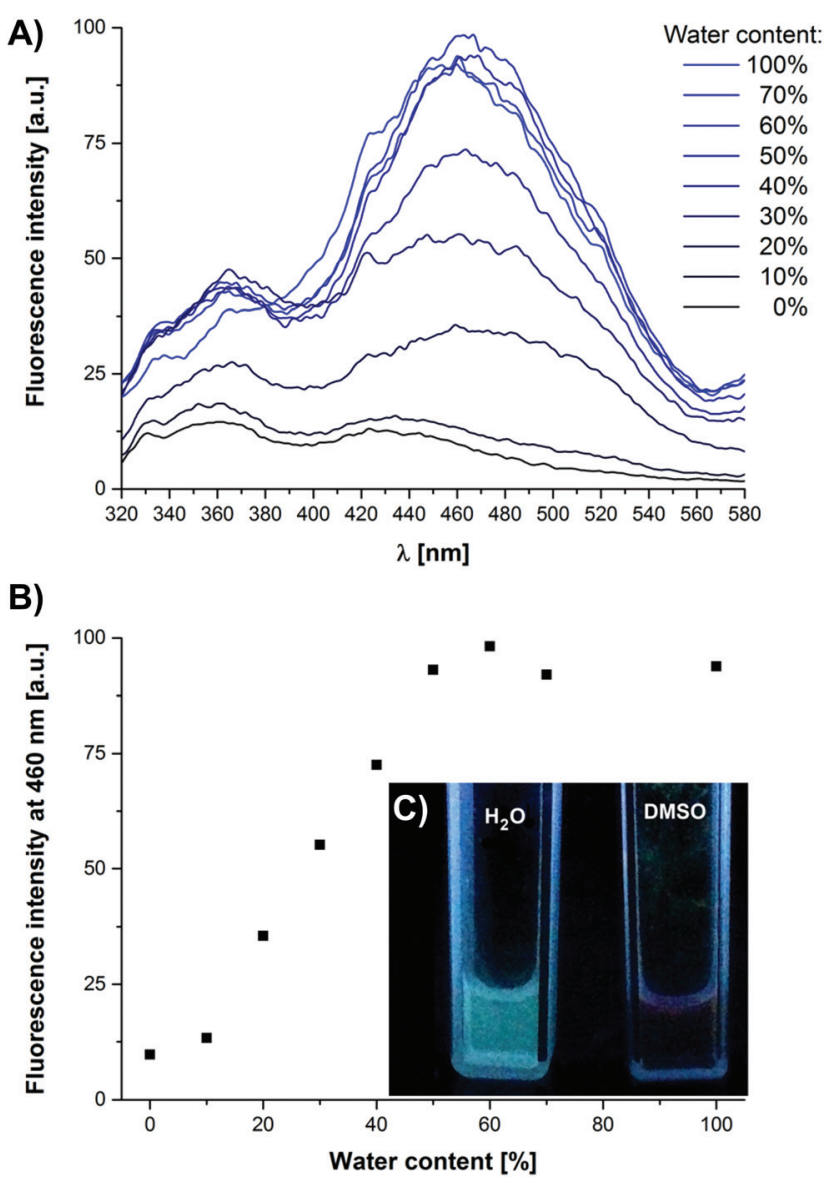

Fig. 3 (A) Photoluminescence emission of $1(25 \mu \mathrm{M})$ in $\mathrm{DMSO} / \mathrm{H}_{2} \mathrm{O}$ (25 mM phosphate buffer, pH 7.4) mixtures. (B) Intensity of the photoluminescence emission at $\lambda_{\mathrm{em}}=460 \mathrm{~nm}\left(\lambda_{\mathrm{exc}}=285 \mathrm{~nm}\right)$ as a function of water content in vol\%. (C) Photograph of compound 1 in buffered $\mathrm{H}_{2} \mathrm{O}$ and in DMSO under UV light irradiation.
Using the aggregation induced luminescence properties of 1, we further investigated the stability of the rod-like micelles towards dilution and aimed to determine the critical aggregation concentration (CAC). The dilution of $\mathbf{1}$ in phosphate buffer (10 mM, pH 7.4) from $12.5 \mu \mathrm{M}$ to $200 \mathrm{nM}$ leads to a linear decrease of the aggregate specific emission intensity (Fig. S1 $\dagger$ ) at $\lambda_{\mathrm{em}}=460 \mathrm{~nm}$. It was thus not possible to determine the CAC since it is below the detection limit of our luminescence spectrometer, but we can estimate an upper limit of $200 \mathrm{nM}$. To further investigate the high stability of the self-assembled dendronised cationic amphiphile 1, we performed $\mathrm{pH}$ dependent photoluminescence experiments, complementary to $\mathrm{CD}$ spectroscopic investigations (Fig. 4A). By lowering the $\mathrm{pH}$ from 7.4 to $\mathrm{pH} 3.2$, the aggregate specific emission band $\lambda_{\mathrm{em}}=460 \mathrm{~nm}$ decreases, but only by $10 \%$ in intensity. The TEM images of $1(100 \mu \mathrm{M})$ at $\mathrm{pH} 3.2$
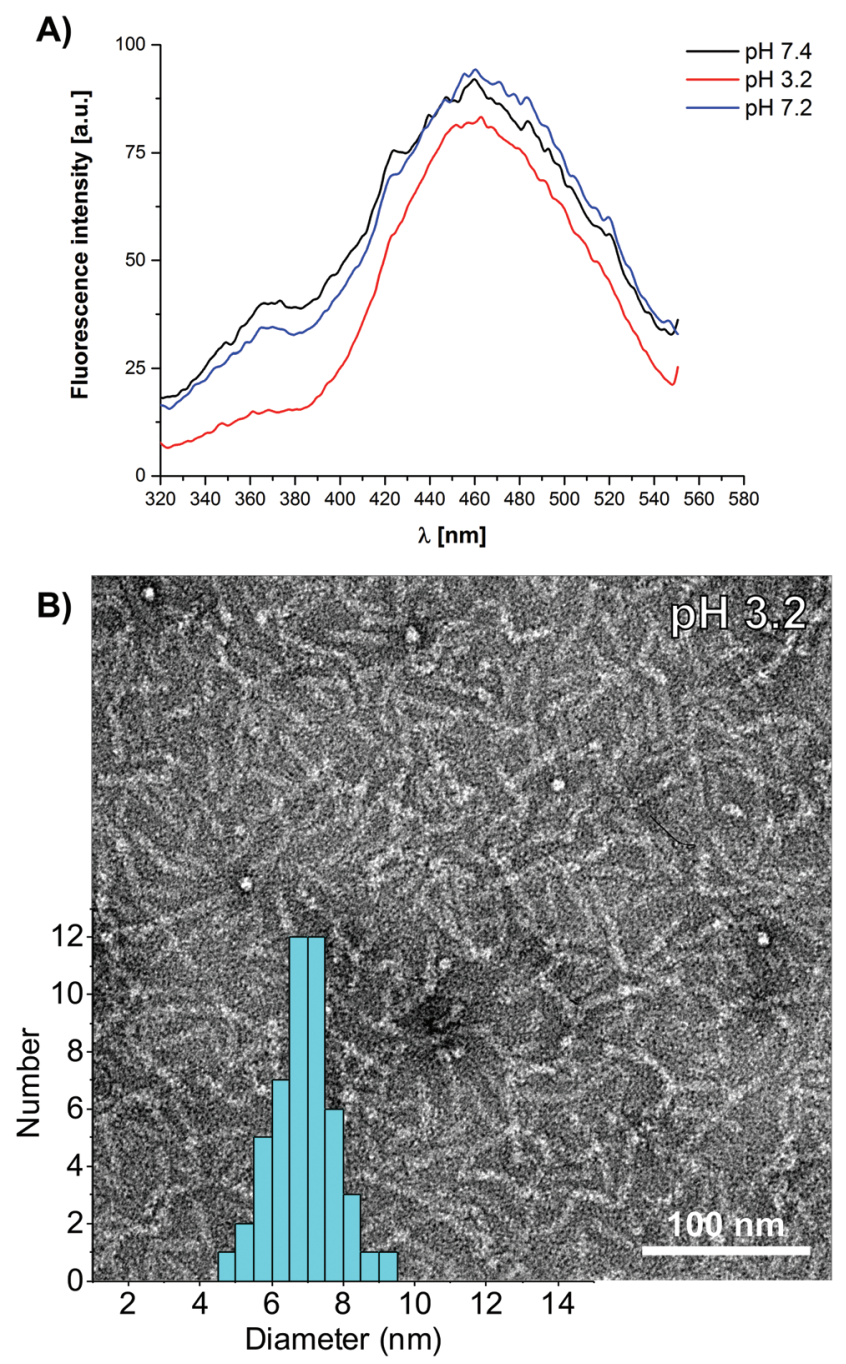

Fig. 4 (A) $\mathrm{pH}$ dependent photoluminescence measurements in $25 \mathrm{mM}$ phosphate buffer. (B) Negative stain TEM image of the rod-like micelles deposited from a $100 \mu \mathrm{M}$ solution of 1 at pH 3.2 (10 mM Tris buffer) and the distribution of the rod diameter. 
reveal the presence of semi-flexible nanorods with a uniform thickness of $6.8 \pm 0.8 \mathrm{~nm}$, thereby confirming that the assemblies are very stable and stay intact even after protonation of the imidazole groups. The addition of a base to the $\mathrm{pH} 3.2$ solution of 1 restores the aggregate specific band to its original intensity at a neutral $\mathrm{pH}$ of 7.2 (Fig. 4A). This observation is in agreement with our tentative conclusion from the $\mathrm{pH}$ dependent $\mathrm{CD}$ data. Reversible protonation of the histidine side chain residues leads to an increased hydrophilicity and lateral swelling of the ordered core in the rod-like micelles.

To corroborate our hypothesis from the $\mathrm{CD}$ and luminescence spectroscopic data, we further performed encapsulation experiments with Nile Red (NR), a hydrophobic solvatochromic dye, in order to probe the polarity of the core of the rod-like micelles (Fig. S2 $\dagger$ ). When adding Nile Red $(5 \mu \mathrm{M})$ to a solution of $1(25 \mu \mathrm{M})$ in phosphate buffer at pH 7.4, we observed a fluorescence emission at $\lambda_{\mathrm{em}}=621 \mathrm{~nm}\left(\lambda_{\mathrm{exc}}=550 \mathrm{~nm}\right)$. This value compares very well with the published studies using encapsulated NR in lipid bilayers, peptide aggregates and artificial supramolecular systems, ${ }^{59-65}$ and suggests that the dye is incorporated in an apolar microenvironment. When reducing the $\mathrm{pH}$ of a solution of self-assembled $\mathbf{1}$ and encapsulated NR to $\mathrm{pH} 2.8$, we observed a weak bathochromic shift of $4 \mathrm{~nm}$ to $\lambda_{\mathrm{em}}=625 \mathrm{~nm}$, and a decrease in the fluorescence intensity of $4 \%$. Both indicate that the microenvironment becomes slightly more hydrophilic but that the NR dye remains encapsulated within the assemblies. In summary, we have used a host of optical spectroscopic techniques to probe the molecular order and stability of the rod-like micelles. Hydrophobic desolvation and the $\beta$-sheet secondary structure lead to one-dimensional self-assembly, which is not switched off by protonation of the basic side chain moieties in the peptide core. In contrast to the linear oligohistidine peptide amphiphiles reported by the Stupp lab, ${ }^{66}$ a decrease in the $\mathrm{pH}$ therefore does not lead to a disassembly of the nanostructures, but rather swelling of the hydrophobic core.

The high stability of the FHFHF based supramolecular nanostructures was investigated in physiologically relevant media, under isotonic conditions and finally also in the presence of serum albumin. A solution of $1(100 \mu \mathrm{M})$ in isotonic phosphate buffered saline (PBS, $137 \mathrm{mM} \mathrm{NaCl}, 2.7 \mathrm{mM} \mathrm{KCl}$, $\mathrm{pH}$ 7.4) was characterised using TEM. Note that we usually use Tris buffer to perform negative stain TEM in order to avoid artefacts due to phosphate salts. ${ }^{40,67}$ Nevertheless, after deposition of a solution of $\mathbf{1}$ in PBS buffer on the TEM grids, rodlike nanostructures can clearly be observed in the electron microscopy images, with an average diameter of $7.1 \pm 1.1 \mathrm{~nm}$ (Fig. 5A). Finally we used the aggregation induced luminescence of self-assembled $\mathbf{1}$ in order to probe the stability of the assemblies in artificial serum, which is critical for applications in supramolecular drug delivery vehicles and in synthetic vaccines. Albumin accounts for approximately $60 \%$ of the proteins in blood, ${ }^{68}$ and is known to strongly effect the self-assembly of amphiphiles due to molecular crowding effects ${ }^{34,69}$ and to disrupt the formation of micelles by the absorption of single
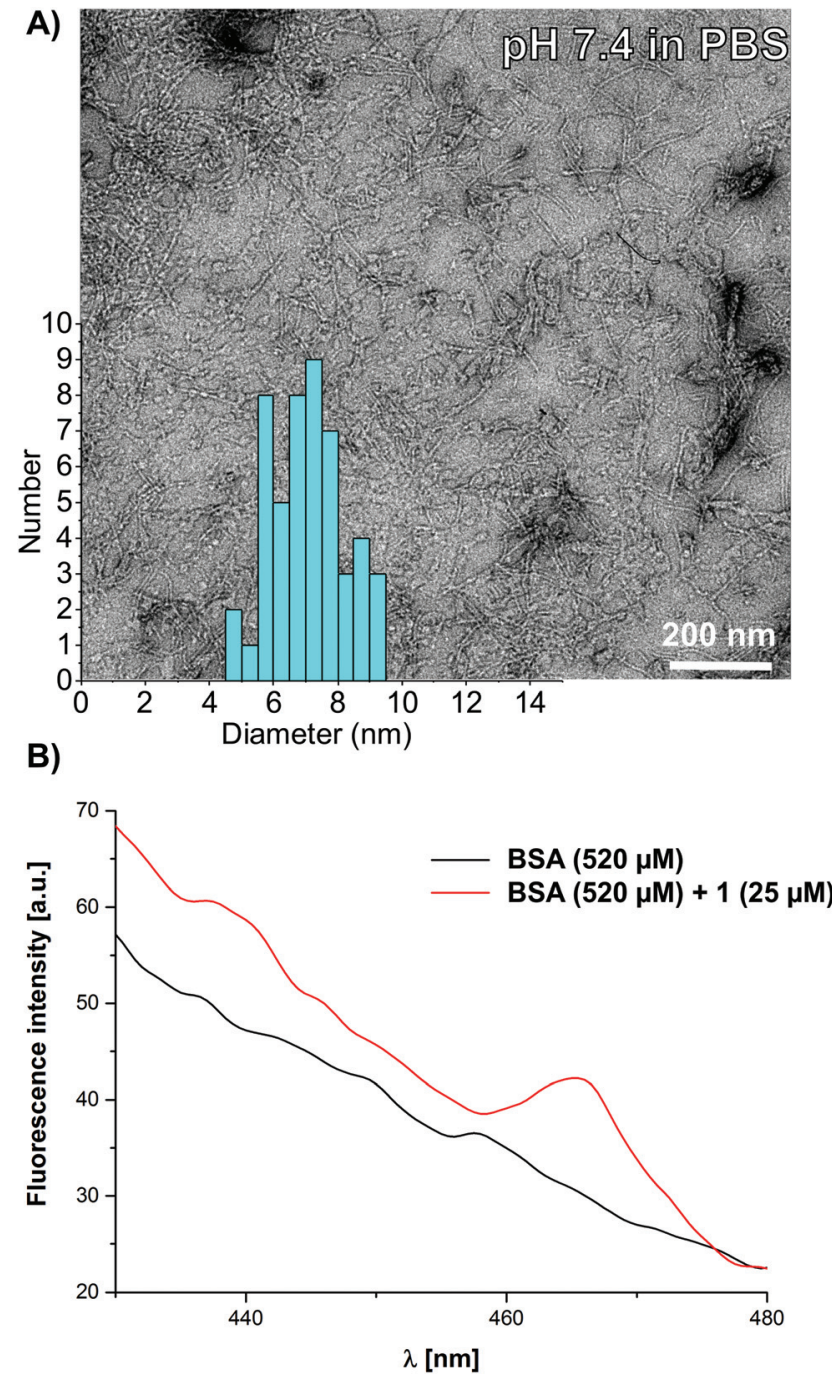

Fig. 5 (A) Negative stain TEM image of the rod-like micelles deposited from a $100 \mu \mathrm{M}$ solution of 1 in $\mathrm{pH} 7.4$ phosphate buffered saline (PBS) and the distribution of the rod diameter. (B) Photoluminescence measurements of BSA $\left(520 \mu \mathrm{M}, 33 \mathrm{mg} \mathrm{ml}^{-1}\right)$ in isotonic PBS with 1 (25 $\mu \mathrm{M}, 100 \mu \mathrm{g} \mathrm{ml}^{-1}$, red curve) and without 1 (black curve).

molecules. ${ }^{70,71}$ The addition of bovine serum albumin (BSA, $\left.520 \mu \mathrm{M}, 33 \mathrm{mg} \mathrm{ml}^{-1}\right)$ to a solution of $1\left(25 \mu \mathrm{M}, 100 \mu \mathrm{g} \mathrm{ml} \mathrm{m}^{-1}\right)$ in PBS buffer does not lead to disassembly of the aggregates, based on photoluminescence spectroscopy. The characteristic emission band of 1 monitored at $\lambda_{\mathrm{em}}=460 \mathrm{~nm}$ was detected over the autofluorescence of the serum albumin, which was present in a 330 fold excess by weight. These findings finally confirm the excellent stability of the rod-like assemblies based on $C_{2}$-symmetric peptide amphiphiles 1 , even in dilute solutions and in the presence of a huge excess of BSA (Fig. 5B). We have thereby designed a very robust peptide based selfassembly building block using a 4,5-bis-(phenylthio)phthalonitrile central core that enables us to probe aggregation processes in a complex and physiologically relevant serum-like medium. 


\section{Conclusions}

We have synthesised a new $C_{2}$-symmetric peptide amphiphile equipped with an aggregation induced emission luminophore. An alternating phenyl alanine-histidine pentapeptide sequence FHFHF was extended with a water solubilising dendritic polycationic group and coupled to the hydrophobic 4,5bis-(phenylthio)phthalonitrile core. In water a combination of hydrophobic shielding and $\beta$-sheet formation leads to anisotropic growth into ordered rod-like micelles. These nanostructures are remarkably stable, and the aggregation induced luminescence properties were used to estimate the upper limit for the critical aggregation concentration of $<200 \mathrm{nM}$. The nanostructures are robust and stay intact in neutral and acidic buffer, in phosphate buffered saline and critically also in the presence of serum albumin. Compared to conventional design strategies we will be able to combine this new supramolecular synthon with our previously reported route for ampholytic copolymers in order to prepare highly robust, yet dynamic and tuneable pH-labile nanorods as delivery vehicles for applications in the intracellular release of cargo material.

\section{Acknowledgements}

We gratefully acknowledge the support from the DFG collaborative research centre SFB 1066 [D. S. and P. B.].

\section{Notes and references}

$\$$ In methanol we observe an intensity weighted average fluorescence lifetime $\tau=3 \mathrm{~ns}$, which is typical of small organic fluorophores (Fig. S3-S6 $\dagger$ ).

1 C. Fouquey, J.-M. Lehn and A.-M. Levelut, Adv. Mater., 1990, 2, 254-257.

2 J.-M. Lehn, Angew. Chem., Int. Ed. Engl., 1990, 29, 13041319.

3 R. P. Sijbesma, F. H. Beijer, L. Brunsveld, B. J. B. Folmer, K. J. H. K. Hirschberg, R. F. M. Lange, J. K. L. Lowe and E. W. Meijer, Science, 1997, 278, 1601-1604.

4 L. Brunsveld, B. J. B. Folmer, E. W. Meijer and R. P. Sijbesma, Chem. Rev., 2001, 101, 4071-4097.

5 D. Zhao and J. S. Moore, Org. Biomol. Chem., 2003, 1, 34713491.

6 T. F. A. de Greef, M. M. J. Smulders, M. Wolffs, A. P. H. J. Schenning, R. P. Sijbesma and E. W. Meijer, Chem. Rev., 2009, 109, 5687-5754.

7 Z. Chen, A. Lohr, C. R. Saha-Möller and F. Würthner, Chem. Soc. Rev., 2009, 38, 564-584.

8 C. Rest, R. Kandanelli and G. Fernandez, Chem. Soc. Rev., 2015, 44, 2543-2572.

9 E. Krieg, M. M. C. Bastings, P. Besenius and B. Rybtchinski, Chem. Rev., 2016, 116, 2414-2477.

10 T. Aida, E. W. Meijer and S. I. Stupp, Science, 2012, 335, 813-817.
11 R. Chapman, M. Danial, M. L. Koh, K. A. Jolliffe and S. Perrier, Chem. Soc. Rev., 2012, 41, 6023-6041.

12 J. Montenegro, M. R. Ghadiri and J. R. Granja, Acc. Chem. Res., 2013, 46, 2955-2965.

13 J. D. Hartgerink, E. Beniash and S. I. Stupp, Science, 2001, 294, 1684-1688.

14 J. D. Hartgerink, E. Beniash and S. I. Stupp, Proc. Natl. Acad. Sci. U. S. A., 2002, 99, 5133-5138.

15 G. A. Silva, C. Czeisler, K. L. Niece, E. Beniash, D. A. Harrington, J. A. Kessler and S. I. Stupp, Science, 2004, 303, 1352-1355.

16 A. M. Smith, R. J. Williams, C. Tang, P. Coppo, R. F. Collins, M. L. Turner, A. Saiani and R. V. Ulijn, Adv. Mater., 2008, 20, 37-41.

17 S. Fleming and R. V. Ulijn, Chem. Soc. Rev., 2014, 43, 81508177.

18 V. Percec, A. E. Dulcey, M. Peterca, M. Ilies, M. J. Sienkowska and P. A. Heiney, J. Am. Chem. Soc., 2005, 127, 17902-17909.

19 H. Frisch, J. P. Unsleber, D. Lüdeker, M. Peterlechner, G. Brunklaus, M. Waller and P. Besenius, Angew. Chem., Int. Ed., 2013, 52, 10097-10101.

20 K. Petkau-Milroy and L. Brunsveld, Org. Biomol. Chem., 2013, 11, 219-232.

21 Y. Bae, S. Fukushima, A. Harada and K. Kataoka, Angew. Chem., Int. Ed., 2003, 42, 4640-4643.

22 A. K. H. Hirsch, F. Diederich, M. Antonietti and H. G. Börner, Soft Matter, 2010, 6, 88-91.

23 J. Shi, A. R. Votruba, O. C. Farokhzad and R. Langer, Nano Lett., 2010, 10, 3223-3230.

24 A. G. Cheetham, P. Zhang, Y.-A. Lin, L. L. Lock and H. Cui, J. Am. Chem. Soc., 2013, 135.

25 K. Miyata, N. Nishiyama and K. Kataoka, Chem. Soc. Rev., 2012, 41, 2562-2574.

26 J. A. Hubbell and A. Chilkoti, Science, 2012, 337, 303-305.

27 J. Nicolas, S. Mura, D. Brambilla, N. Mackiewicz and P. Couvreur, Chem. Soc. Rev., 2013, 42, 1147-1235.

28 M. Talelli, M. Barz, C. J. F. Rijcken, F. Kiessling, W. E. Hennink and T. Lammers, Nano Today, 2015, 10, 93117.

29 J. S. Rudra, Y. F. Tian, J. P. Jung and J. H. Collier, Proc. Natl. Acad. Sci. U. S. A., 2010, 107, 622-627.

30 J. S. Rudra, T. Sun, K. C. Bird, M. D. Daniels, J. Z. Gasiorowski, A. S. Chong and J. H. Collier, ACS Nano, 2012, 6, 1557-1564.

31 M. A. Swartz, S. Hirosue and J. A. Hubbell, Sci. Transl. Med., 2012, 4, 148rv149.

32 L. Nuhn, S. Hartmann, B. Palitzsch, B. Gerlitzki, E. Schmitt, R. Zentel and H. Kunz, Angew. Chem., Int. Ed., 2013, 52, 10652-10656.

33 S. R. Bull, M. O. Guler, R. E. Bras, T. J. Meade and S. I. Stupp, Nano Lett., 2004, 5, 1-4.

34 P. Besenius, J. L. M. Heynens, R. Straathof, M. M. L. Nieuwenhuizen, P. H. H. Bomans, E. Terreno, S. Aime, G. J. Strijkers, K. Nicolay and E. W. Meijer, Contrast Media Mol. Imaging, 2012, 7, 356-361. 
35 P. Y. W. Dankers and E. W. Meijer, Bull. Chem. Soc. Jpn., 2007, 80, 2047-2073.

36 A. Mata, Y. Geng, K. J. Henrikson, C. Aparicio, S. R. Stock, R. L. Satcher and S. I. Stupp, Biomaterials, 2010, 31, 60046012.

37 J. B. Matson and S. I. Stupp, Chem. Commun., 2012, 48, 2633.

38 M. J. Webber, E. A. Appel, E. W. Meijer and R. Langer, Nat. Mater., 2016, 15, 13-26.

39 M. von Gröning, I. de Feijter, M. C. A. Stuart, I. K. Voets and P. Besenius, J. Mater. Chem. B, 2013, 1, 2008-2012.

40 H. Frisch, Y. Nie, S. Raunser and P. Besenius, Chem. - Eur. J., 2015, 21, 3304-3309.

41 R. Appel, S. Tacke, J. Klingauf and P. Besenius, Org. Biomol. Chem., 2015, 13, 1030-1039.

42 R. Appel, J. Fuchs, S. M. Tyrrell, P. A. Korevaar, M. C. A. Stuart, I. K. Voets, M. Schönhoff and P. Besenius, Chem. - Eur. J., 2015, 21, 19257-19264.

43 B. Kemper, Y. R. Hristova, S. Tacke, L. Stegemann, L. S. van Bezouwen, M. C. A. Stuart, J. Klingauf, C. A. Strassert and P. Besenius, Chem. Commun., 2015, 51, 5253-5256.

44 J. Luo, Z. Xie, J. W. Y. Lam, L. Cheng, H. Chen, C. Qiu, H. S. Kwok, X. Zhan, Y. Liu, D. Zhu and B. Z. Tang, Chem. Commun., 2001, 1740-1741.

45 B.-K. An, S.-K. Kwon, S.-D. Jung and S. Y. Park, J. Am. Chem. Soc., 2002, 124, 14410-14415.

46 M. K. Müller and L. Brunsveld, Angew. Chem., Int. Ed., 2009, 48, 2921-2924.

47 Y. Hong, J. W. Y. Lam and B. Z. Tang, Chem. Soc. Rev., 2011, 40, 5361-5388.

48 B. Xu, M. Xie, J. He, B. Xu, Z. Chi, W. Tian, L. Jiang, F. Zhao, S. Liu, Y. Zhang, Z. Xu and J. Xu, Chem. Commun., 2013, 49, 273-275.

49 J. Mei, Y. Hong, J. W. Y. Lam, A. Qin, Y. Tang and B. Z. Tang, Adv. Mater., 2014, 26, 5429-5479.

50 D. Ding, K. Li, B. Liu and B. Z. Tang, Acc. Chem. Res., 2013, 46, 2441-2453.

51 K. Petkau-Milroy, M. H. Sonntag, A. H. A. M. van Onzen and L. Brunsveld, J. Am. Chem. Soc., 2012, 134, 8086-8089.

52 P. Ahlers, H. Frisch and P. Besenius, Polym. Chem., 2015, 6, 7245-7250.

53 S. Brahms, J. Brahms, G. Spach and A. Brack, Proc. Natl. Acad. Sci. U. S. A., 1977, 74, 3208-3212.
54 S. E. Paramonov, H.-W. Jun and J. D. Hartgerink, J. Am. Chem. Soc., 2006, 128, 7291-7298.

55 H. Jiang, M. O. Guler and S. I. Stupp, Soft Matter, 2007, 3, 454-462.

56 P. Besenius, K. P. van den Hout, H. M. H. G. Albers, T. F. A. de Greef, L. L. C. Olijve, T. M. Hermans, B. F. M. de Waal, P. H. H. Bomans, N. A. J. M. Sommerdijk, G. Portale, A. R. A. Palmans, M. H. P. van Genderen, J. A. J. M. Vekemans and E. W. Meijer, Chem. - Eur. J., 2011, 17, 5193-5203.

57 P. Besenius, G. Portale, P. H. H. Bomans, H. M. Janssen, A. R. A. Palmans and E. W. Meijer, Proc. Natl. Acad. Sci. U. S. A., 2010, 107, 17888-17893.

58 W. Rettig, Angew. Chem., Int. Ed. Engl., 1986, 25, 971-988.

59 P. Greenspan and S. D. Fowler, J. Lipid Res., 1985, 26, 781789.

60 M. Sutter, S. Oliveira, N. N. Sanders, B. Lucas, A. Hoek, M. A. Hink, A. J. W. G. Visser, S. C. Smedt, W. E. Hennink and W. Jiskoot, J. Fluoresc., 2007, 17, 181-192.

61 B. Demeule, R. Gurny and T. Arvinte, Int. J. Pharm., 2007, 329, 37-45.

62 A. Hawe, M. Sutter and W. Jiskoot, Pharm. Res., 2008, 25, 1487-1499.

63 R. Mishra, D. Sjolander and P. Hammarstrom, Mol. BioSyst., 2011, 7, 1232-1240.

64 J. Boekhoven, A. M. Brizard, P. van Rijn, M. C. A. Stuart, R. Eelkema and J. H. van Esch, Angew. Chem., Int. Ed., 2011, 50, 12285-12289.

65 I. de Feijter, P. Besenius, L. Albertazzi, E. W. Meijer, A. R. A. Palmans and I. K. Voets, Soft Matter, 2013, 9, 10025-10030.

66 T. J. Moyer, J. A. Finbloom, F. Chen, D. J. Toft, V. L. Cryns and S. I. Stupp, J. Am. Chem. Soc., 2014, 136, 14746-14752.

67 M. Ohi, Y. Li, Y. Cheng and T. Walz, Biol. Proced. Online, 2004, 6, 23-34.

68 H. A. Krebs, Annu. Rev. Biochem., 1950, 19, 409-430.

69 A. Ghosh, C. J. Buettner, A. A. Manos, A. J. Wallace, M. F. Tweedle and J. E. Goldberger, Biomacromolecules, 2014, 15, 4488-4494.

70 H. Chen, S. Kim, W. He, H. Wang, P. S. Low, K. Park and J.-X. Cheng, Langmuir, 2008, 24, 5213-5217.

71 J. Lu, S. C. Owen and M. S. Shoichet, Macromolecules, 2011, 44, 6002-6008. 